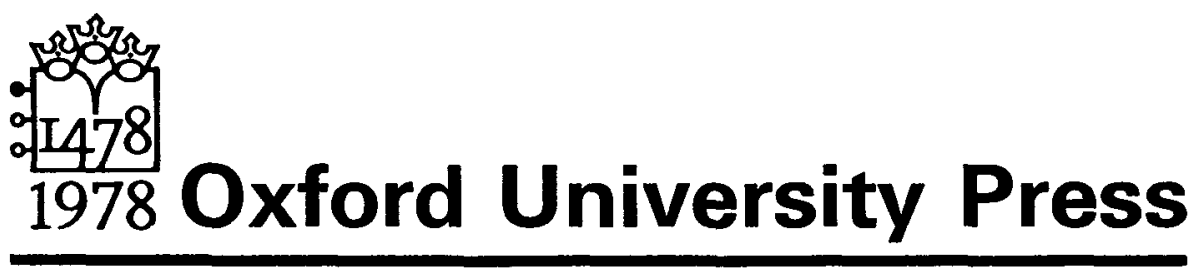

\title{
Growing Out of Poverty
}

\section{Edited by Elizabeth Stamp}

Throughout the poorer areas of the world small groups of people, with modest assistance from Oxfam and other voluntary agencies, are working hard to make better use of agricultural resources, and so grow more food. The stories of some of these groups are told in this book. Written as vivid personal accounts, they range from making better use of land in the highlands of Guatemala to the search for animal protein in a Cameroon village. Illustrated $€ 4.25$ paper covers $€ 1.95$

\section{The Financing of Economic Development}

\section{W. T. Newlyn}

The aim of this book is to consolidate and add to existing knowledge of the financial aspects of economic development. It includes case studies from three south Asian and four African countries. The book fills a gap in university reading lists for courses in developments, and will be intelligible to any reader with a minimal knowledge of economic analysis. $£ 10$

\section{University Development in Africa}

The Nigerian Experience

V. Chukwuemeka lke

This personal view of the problems of the emerging Nigerian university is intended to stimulate discussion on university development in Africa generally. $\mathbf{1 1 7}$

\section{Journal of Southern African Studies}

This journal aims at generating fresh scholarly inquiry and exposition in the fields of economics, sociology, demography, social anthropology, administration, law, political science, international relations, history, and the natural sciences in so far as they relate to the human condition. The approach is at all times objective - to present material selected on the basis of scholarship and not for any ideological commitment. Twice yearly $£ 6$ (US $\$ 15$ ) p.a. Single issues $£ 3.50$ (US \$8). 


\section{The Critical Phase in Tanzania, 1945-1968}

Nyerere and the Emergence of a Socialist Strategy

CRANFORD PRATT

Professor Pratt traces in detail the political and governmental experiences from 1959 to 1967 which led President Julius Nyerere and his party, the Tanganyika African National Union, to their recommitment to socialism. Close attention is given to the political strategy by which Nyerere hoped to accomplish this socialist transformation.

68.50 net

\section{Population, Prosperity and Poverty}

\section{Rural Kano 1900 and 1970}

\section{POLLY HILL}

This book reports on field work done in an exceedingly densely populated locality of rural Hausaland in 1971-72; in addition, Polly Hill utilises archival material on the rural Kano Emirate in very early colonial times.

\$8.50 net

\section{CAMBRIDGE UNIVERSITY PRESS}

\section{UNIVERSITY OF ZAMBIA INSTITUTE FOR AFRICAN STUDIES \\ (formerly Rhodes-Livingstone Institute) \\ P.O. Box 900, Lusaka, Zambia}

PUblications:

African Social Research (bi-annual journal)

Zambian Papers (annual)

Communications (annual)

African Social Research No. 24 SPECIAL ANNIVERSARY IsSUE

Articles by former Directors of the Institute: Audrey Richards, Monica Wilson, Elizabeth Colson, J. Clyde Mitchell, Henry Fosbrooke, C. N. M. White, Alastair Heron and Philip Nsugbe, with a prologue by H. J. Simons

\section{Book Reviews}

SUBSCRIPTIONS:

Full Subscriptions entitle Subscribers to receive two copies of African Social Research and one issue of Zambian Papers and Communications per annum, post free.

Rates are:

East and Central Africa

K10.00

United States and Canada:

Institutional

Personal

$\$ 20.00$

United Kingdom and elsewhere $\quad £ 9.00$ 


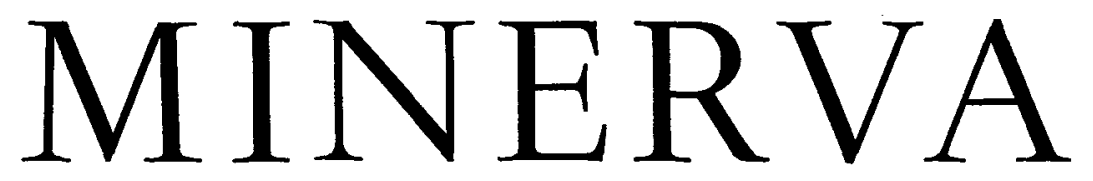

A Review of Science, Learning and Policy

\section{Editor: Edward Shils}

\section{ARTICLES}

Science Courts Allan Mazur

The Criteria of Choice in Medical Policy: Radiotherapy in Massachusetts Muriel Gillick

Autonomy and Accountability of Basic Research Heather Johnston Nicholson

The Promotion of Mobility of Scientists: A Problem of French Science Policy Ronald Brickman

\section{REPORTS AND DOCUMENTS}

The International Scientific Community: Ideas Move Around Inside People John Ziman

$$
\text { BOOK REVIEWS }
$$

A. Hunter Dupree, Joseph Ben-David, P. B. Medawar

Annual subscription $£ 8.00 / \$ 18.00$. Single copy $£ 2.50 / \$ 5.00$ MINERVA, 59 St Martin's Lane, London WC2N 4JS 
Edited by Phyllis M. Martin and Patrick O'Meara, maps and charts by Cathrya L. Lombardi, photographic selection by Mary Joy Pigonzi

A comprehensive interdisciplinary study consisting of twenty-four essays in which well-known scholars discuss African history, politics, economics, religion, art, literature, music, social organization, race relations, and the international dimensions of African affairs. 480 pages, photos, maps, charts, tables, diagrams. bibl. $\$ 20.00$

\section{Primitive Government}

\section{A Study of Traditional Political Systems in Eastern Africa}

By Lucy Mair

This updated edition of a classic anthropological work describes many types of government in traditional Africa. " . . an important and first-rate piece of work: a model of clear exposition, marked by the qualities of conciseness and cogency that Dr. Mair's colleagues have come to expect from her." -Africa 288 pages cloth $\$ 10.95$ paper $\$ 3.95$

\section{Southern Africa In Crisis}

Edited.by Gwendolen M. Carter and Patrick O'Meara, Introduction by Colin Legum “... in the category of 'must reading' if students of international and military affairs are to have a basic understanding of current events in southern Africa. ... . timely and analytical ... a work of major sigmificance in the field of contemporary international relations." -Parameters, Journal of the US Army War College 288 pages, maps, bibl. $\$ 12.50$

\section{A Gricket In the Thorn Tree}

Helen Suzman and the

Progressive Party of South Africa

By Joanna Strangwayes-Booth

"A biography of one of the bravest political figures in South Africa, and also a handbook of South African politics from the end of the Second World War." -The New Yorker ". . . a well-written and fascinating political biography." -Political Science Quarterly 320 pages $\$ 12.50$

\section{South African Political materials}

\section{A Catalogue of the Carter-Karis Collection}

Edited by Gwendolen M. Carter and Thomas Karis

For students of South African political developments and particularly of African nationalist movements in South Africa, this long-awaited catalogue provides the key to a unique collection of materials now available on seventy-one reels of microfilm. Includes secondary as well as primary materials. 830 pages $\$ \$ 35.00$ 


\section{THE JOURNAL OF MODERN AFRICAN STUDIES}

The Journal offers a quarterly survey of politics, economics, and related topics in contemporary Africa.

The main emphasis is upon the peoples and policies, the problems and progress of this dynamic and disparate continent; upon the many societies that are evolving rather than the essential characteristics of the old; upon the present, not on the more distant past. The best current work is sought from specialists in different academic disciplines, whose contributions can illuminate and crossfertilise one another.

The fournal seeks to promote a deeper understanding of what is happening in Africa today. It is intended for both the political scientist and the practical politician, the administrator and the advocate, the economist and the educator, the banker and the business man, the diplomat and the technocrat, the civil servant and the nationalist leader. All have something to contribute to these pages and, it is hoped, much to learn from them.

Editorial policy avoids commitment to any political viewpoint or ideology, whether imperialism, pan-Africanism, capitalism, socialism, or nationalism. Such concepts, however, have relevance to the modern African situation, and merit serious discussion, often from several different points of view, in order that controversial issues may be fairly examined.

Contributors of accepted articles will be asked to assign their copyright, on certain conditions, to Cambridge University Press, to help protect their material, particularly in the U.S.A.

(C) Cambridge University Press 1978

For permission to reproduce material from The Fournal of Modern African Studies, please apply to the London or New York office of Cambridge University Press.

ISI Tear Service, 325 Chestnut Street, Philadelphia, Pennsylvania I9106, U.S.A. is authorised to supply single copies of separate articles for private use only. 


\section{CAMBRIDGE UNIVERSITY PRESS}

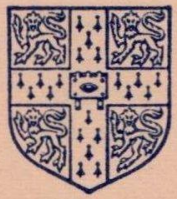

The Pitt Building, Trumpington Street, Cambridge CB2 1RP

Bentley House, 200 Euston Road, London NW1 2DB

32 East 57 th Street, New York, N.Y. 10022

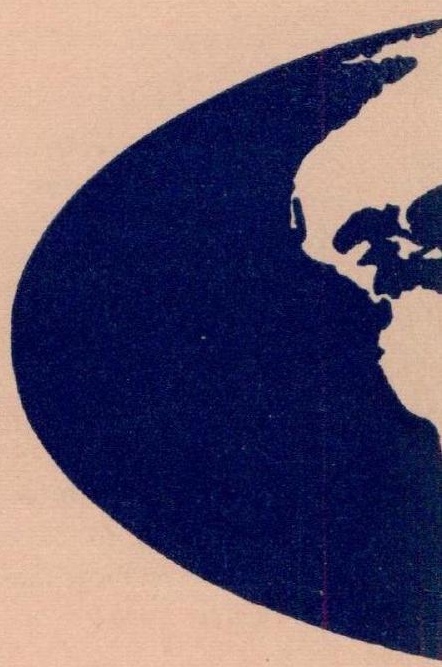

C) Cambridge University Press 1978 